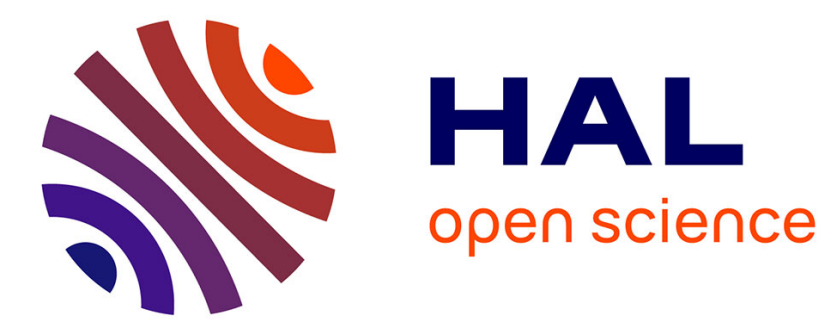

\title{
Living by Default
}

Christophe Salvat

\section{To cite this version:}

Christophe Salvat. Living by Default. Journal of Economic Methodology, 2017, 24 (4), 10.1080/1350178X.2017.1368872 . halshs-01590753

\section{HAL Id: halshs-01590753 https://shs.hal.science/halshs-01590753}

Submitted on 20 Sep 2017

HAL is a multi-disciplinary open access archive for the deposit and dissemination of scientific research documents, whether they are published or not. The documents may come from teaching and research institutions in France or abroad, or from public or private research centers.
L'archive ouverte pluridisciplinaire HAL, est destinée au dépôt et à la diffusion de documents scientifiques de niveau recherche, publiés ou non, émanant des établissements d'enseignement et de recherche français ou étrangers, des laboratoires publics ou privés. 


\section{Living by default}

Choosing not to choose. Understanding the Value of Choice, Cass Sunstein, Oxford and New York, Oxford University Press, 2015, 219p, 29.95\$ (hardback), ISBN 978-0-19-023169-9

Choosing not to choose, the latest book by Cass Sunstein (author of Nudge), discusses the benefits one might expect from the generalisation of default rules in our society. The advantages offered by default rules have been corroborated by numerous studies in behavioural economics and have been extensively used to defend a new type of paternalism (Thaler and Sunstein 2008, Sunstein 2014a, b), often referred as referred to as libertarian or behavioural paternalism (Salvat 2014, Rizzo 2016, Lecouteux 2016). While Sunstein's previous works discuss the benefits of default rules and other paternalistic policies, Choosing not to choose specifically addresses the pros and cons of impersonal as well as personal default rules. Sunstein's ideas are less ideologically biased and more rigorously argued than in his other books and, more importantly, by introducing a distinction between impersonal and personal rules, he makes a real contribution to the debate on behavioural paternalism.

Default rules such as an opt out clause, Sunstein argues, save valuable time and energy whilst improving the efficiency of individual choices. Sunstein develops a truly critical theory of such rules and does not merely defend the principle but appreciates the relative benefit on a case-by-case basis. It would therefore be excessive to present this book as an unqualified statement in favour of passivity or absence of choice, but voluntary submission to default rules ought to be considered as a valid and legitimate choice, one that each individual is free to make.

\section{Choice-requiring paternalism is not an oxymoron}

The main thesis of the book is that people prefer not to make a choice or active decision and that they have good reasons for this. Whilst refraining from choosing is frowned upon in societies where freedom of opinion has been hard fought, Sunstein interestingly argues that not choosing is itself a choice to be respected. People ought not to be forced to choose when they do not want to, claims 
Sunstein. They should not be forced to vote, nor should they be forced to choose a health insurance policy, or to be an organ donor if they do not want to. People should recognise that freedom of choice also includes the freedom not to choose; the former arguably cannot be a "freedom" without the latter caveat. If people are given the choice to "opt out from active choosing", then inciting them not to choose is an instance of libertarian paternalism (Sunstein 2015, 115). If they are actually forced to choose, this is plainly 'wrong' paternalism.

As a long-time advocate of default rules, Sunstein in the ground-breaking article 'Is Libertarian Paternalism an Oxymoron?' co-written with the economist Richard Thaler, has already voiced support for the generalization of default rules (Sunstein and Thaler 2003). The difference between his previous and current work lies in the justification and the scope he gives to the use of default rules. The main difference in terms of supporting arguments is that, unlike his previous works, Choosing not to Choose does not justify default rules based on increased well-being, but on the improvement of the decision-making process one could expect from the agent. Elaborating on Kahneman's Thinking Fast and Slow, Sunstein claims that slow, conscious and calculating thinking (System 2 ) is very demanding in terms of information and very consuming in terms of time and energy, and this explains why people prefer to use it only when necessary. Every time this is possible, i.e. when they face familiar situations or when customary rules have proved to be efficient, people are better off using fast, automatic and instinctive thinking (System 1). According to Sunstein, properly designed default rules are an efficient way of using System 2. They can indistinctively apply to everyone (impersonal default rules) or be specifically designed to meet the needs of a particular population (personalized default rules). The choice between choosing or not choosing therefore first depends on the nature of the default rule proposed.

Let us start with the most common type of situation, the one for which an impersonal default rule might be preferred to making an active choice. This is the kind of situation encountered in Nudge (Thaler and Sunstein 2008, Sunstein 2014b). According to Sunstein, impersonal default rules are preferable 1) when the context is confusing, technical, and unfamiliar, 2) when people prefer not to choose, 3) when learning is not important and 4) when the population is not heterogeneous along any relevant dimension (Sunstein 2015,18 ). Alternatively, active choosing is preferable 1 ) when choice architects are biased or lack important information, 2) when the context is familiar or nontechnical, 3) when people actually prefer to choose, 4) when learning matters and 5) when there is a relevant heterogeneity (Sunstein 2015, 18-19). I would like to point out that, contrary to previous works (think of the cafeteria example in Nudge), Sunstein acknowledges the possibility for the choice architect to be biased or simply wrong. Clause 1 and clauses 3 to 5 are perfectly reasonable grounds 
to choose between choosing or not choosing but clause number 2, I shall argue, is not. Having a preference to choose or not to choose is not a legitimate reason to (or not to) comply with impersonal default rules.

\section{Preference not to choose}

It is unclear what Sunstein really means when he refers to a preference not to choose. A first possibility is that, in a particular case and considered the cost associated to the decision-making process, people prefer not having to choose. This is what seems to be implied in the following quotation: "some people choose not to choose. Sometimes they make that choice explicitly (and indeed may be willing to pay a considerable amount to people who will choose for them). Sometimes people have made no explicit choice; they have not actively chosen anything. But it is nonetheless reasonable to infer that in particular contexts, their preference is not to choose, and they would say so if they would say so if they were asked." (Sunstein 2015,113$)$. In that case, preferring not to choose would be equivalent to having a vested interest not to choose. But why would Sunstein consider it as a distinct reason not to choose? The fact that I prefer not to choose in a specific context is just the logical outcome of the context being confusing, technical, and unfamiliar etc. The only reason for Sunstein to have included a preference not to choose amongst the reason to prefer default rules is that by preference he means a predilection or a general inclination not to choose.

This raises further difficulties. From a strict logical point of view, first, choosing not to choose is a choice and cannot therefore be justified by a preference not to choose. I could possibly make such a decision once and for all by choosing, for instance, to join a totalitarian state. But even then I would have to make mundane daily choices such as whether to eat pears or apples. We spend our lives making choices, most of which we hardly even notice. One could, of course, understand that some choices are more difficult than others. Some choices are risky and/or require information and expertise. Some may have painful consequences and can be unpleasant to make. Others may simply be too mundane to be worth investing in a decision, however small the cost might be. These examples, among many others, justify individuals in their preference not to choose. But this preference is strictly circumstantiated to the case it applies to. There is no general preference 'not to choose'. The mere idea of such of preference is absurd since individual preferences only exist as long as they can be expressed by choice.

Sunstein's emphasis on individual preferences is understandable, and his work is pervaded by an adhesion to freedom of choice. Acknowledging the possibility of a preference not to choose may, 
however, undermine his whole enterprise. It is one thing to design default rules on the assumption that people may not have an interest in choosing themselves, but it is entirely another to design default rules on the assumption they might not want to make a choice at all. Firstly, while it is reasonably easy to weigh up the reasons agents may have to prefer default rules over active choice (see, among others, the reasons listed above), it is impossible for anyone to sense an alleged preference not to choose. Secondly, acknowledging a preference not to choose is paramount to admitting that some people are content with whatever choice the default rule makes for them. In other words, it comes down to saying that some people have no preferences at all.

\section{Contemplating the future}

To conclude this review, I would like to give the reader an overview of the types of personal default rules Sunstein imagines for our future. Personalized default rules offer considerable advantages over impersonal default rules. They are more efficient since they are specifically adapted for a type of population. They also have better compliance rates because the more they exhibit 'knowledge' of individuals situations, the better they align to people's preferences and the more trusted the default rules become in general. In a world where all our online purchases, communications and even pictures are stored and analysed, it has become technologically possible to set highly personalized default rules for each of us. Some companies already use them to suggest books, music or even clothes we should like. This is called predictive shopping. So far, purchases are only suggested, but Sunstein goes further and proposes the possibility of default purchasing: "Suppose on the basis of such data, a bookseller knows, with certainty or close to it, what people will buy before they know they know themselves. If so, the conclusion seems clear, at least if the goal is to promote people's welfare: People should be defaulted into those purchases." (Sunstein 2015, 176). This is, of course, only an example amongst many others: similar rules could be implemented in all types of situations, the food you eat, the magazines and newspapers you read, the films you see, the furniture you need, and - why not - the partner you date. Sunstein even considers default voting before eventually excluding it: "In fact, it would be easy to construct a system of data mining, producing an algorithm able to specify, with considerable accuracy, how you would vote, or indeed how everyone would vote, so that no one would actually need to vote." (Sunstein 2015,164$)$. The problem, explains Sunstein, is that voting is a very specific type of action, one that is "supposed to represent an active choice, in which voters are engaged, thinking, participating, and selecting among particular candidates" (Sunstein 2015, 164). 
Voting is certainly a different type of choice than, say, buying groceries. But its specificity is more related to its potential consequences rather than the nature of the decision-making process itself. Those who do not take democracy seriously would have no issue with using default voting. If they trust an algorithm to choose which university to go to, which job to apply for and which health insurance to take out, there is no reason why they should not also trust an algorithm that would vote for them. Considering Sunstein's arguments for personalized default rules, it is unjustified to exclude default voting.

This leads me to the main criticism I would address to Sunstein's otherwise very suggestive book. Default rules, as explained, are beneficial to individuals whenever rational deliberation is too demanding for what is at stake. Most of us appreciate buying phones or other electronic devices preinstalled with default settings. This saves us a considerable amount of time and effort that could be better used to make important choices. In Kahneman's terms, the efficiency of system 2 relies on the extent of system 1. This was, or so I believed, Sunstein's initial argument. Yet, as the arguments in the book develop, default rules - and particularly personalized default rules - are contemplated for all possible kinds of situations, even the most important ones. System 1 is expected to grow indefinitely while system 2 shrinks away. What purpose can this possibly serve? Do we really want to live in a world where we would not have to choose anything for ourselves? Nobody would contest the fact that there is a (slight) disutility to making choices, but it is nevertheless something we have to do if we want our life to be really ours. The danger of Sunstein's system is that the more one defaults choices, the more difficult and unpleasant the decision-making process becomes, and the more one is tempted by defaulting, until - one day - one realizes that one lives one's live by default.

\section{References}

Lecouteux, G. (2016). From Homo Economicus to Homo Psychologicus: the Paretian Foundations of Behavioural Paternalism. CEconomia 6 (2), 175-200.

Rizzo, M. J. (2016). The Four Pillars of Behavioral Paternalism. In S. Abdukadirov (ed.), Nudge Theory in Action: Behavioral Design in Policy and Markets, (p.37-63). Cham: Springer International Publishing.

Salvat, C. (2014). Behavioral Paternalism. Revue de Philosophie Economique/ Review of Economic Philosophy, 15 (2), 109-130.

Sunstein, C.R. (2014a). Simpler: The Future of Government. New York \& London: Simon \& Schuster.

Sunstein, C.R. (2014b). Why Nudge?: The Politics of Libertarian Paternalism. New Haven \& London: Yale University Press.

Sunstein, C.R. (2015). Choosing not to Choose. Understanding the Value of Choice. Oxford and New York: Oxford University Press.

Sunstein, C. R., and R. H. Thaler. (2003). Libertarian Paternalism Is Not an Oxymoron. The University of Chicago Law Review, 70 (4), 1159-1202. 
Thaler, R. H., and C. R. Sunstein. 2008. Nudge. Improving Decisions About Health, Wealth, and Happiness. New Haven \& London: Yale University Press.

Christophe Salvat Research Fellow at the National Center for Scientific Research (CNRS), Triangle- Ecole Normale Supérieure de Lyon, Lyon, France

Christophe.salvat@ens-lyon.fr 